\title{
MATHEMATICAL MODELING OF THE KINETICS OF STRAWBERRY PULP CONVECTIVE DRYING AND THE EFFECT OF ASCORBIC ACID ON STRAWBERRY PULP COLOR PRESERVATION MATEMATIČKO MODELOVANJE KINETIKE KONVEKTIVNOG SUŠENJA PULPE OD JAGODE I UTICAJ ASKORBINSKE KISELINE NA OČUVANJE BOJE
}

\author{
Zoran STAMENKOVIĆ*, Ivan PAVKOV*, Milivoj RADOJČIN**, Krstan KEŠELJ", \\ Anita VAKULA**, Tihomir NOVAKOVIĆ* \\ *University of Novi Sad, Faculty of Agriculture, Trg Dositeja Obradovića 8, 21000 Novi Sad, Serbia \\ ${ }^{* *}$ University of Novi Sad, Faculty of Technology, Bulevar cara Lazara 1, 21000 Novi Sad, Serbia \\ e-mail: zoran.stamenkovic@polj.uns.ac.rs
}

\begin{abstract}
The five most widely used mathematical models, which were additionally extended with a dimensionless coefficient (i.e. the drying air temperature), were examined for the best approximation of strawberry pulp convective drying in a thin stagnant layer. Furthermore, the effects of the drying air temperature and ascorbic acid on changes in the color of strawberry pulp during the drying process were examined.

The statistical parameters of the mathematical models (namely $R, X^{2}, R M S E$ ) indicated that the Extended Modified Page model had the best fit for the convective drying of strawberry pulp.

The changes in the color of the dried control sample, without the addition of ascorbic acid, were $\Delta E=22.95$ and $\Delta E=25.71$ at air temperatures of $45^{\circ} \mathrm{C}$ and $65^{\circ} \mathrm{C}$, respectively.

The greatest change in the sample color $(\triangle E=14.66)$ was observed at an air temperature of $45^{\circ} \mathrm{C}$ and an ascorbic acid additive value of $0.5 \%$. However, the smallest change in the sample color $(\Delta E=12.57)$ was observed at an air temperature of $65{ }^{\circ} \mathrm{C}$ with the addition of $1 \%$ ascorbic acid.
\end{abstract}

Key words: strawberry pulp, convective drying kinetics, mathematical modeling, color change, fruit leather.

\section{REZIME}

Rolnice od sušene voćne kaše su proizvod koji se sve više može naći na tržištu. Sirovina za njihovu proizvodnju je voće koje ne odgovora tehnološkim procesima proizvodnje sušenog voća (zrelije voće).

Postupak proizvodnje predstavlja konvektivno sušenje kaše od jagode nanesene na lesu sušare u sloju debljine do 5 mm. Prilikom pripreme voćne kaše i tokom konvektivnog sušenja dolazi do oksidacije voćnog tkiva. Kako bi se smanjio uticaj oksidacije u kašu se dodaju antioksidansi, poput L-askorbinske kiseline.

Ispitan je uticaj temperature vazduha za sušenje $\left(45^{\circ} \mathrm{C} \mathrm{i} 65^{\circ} \mathrm{C}\right)$ i dodatak $L$ - askorbinske kiseline $(0,5 \%$ i $1,5 \%$, od mase pripremljene kaše) na promenu boje krajnjeg poizvoda.

Boja kaše od jagode merena je odmah nakon pripreme i nakon konvektivnog sušenja kaše, kolorimetrom Konika Minolta CR400. Najniža promena boje $\Delta E=12,57$, ostvarena je pri temperaturi vazduha za sušenje od $65^{\circ} \mathrm{C}$ i $1 \%$ dodatku L - askorbinske kiseline.

Najviša promena boje $\Delta E=14,66$, ostvarena je pri temperaturi vazduha za sušenje od $45^{\circ} \mathrm{C} i$ dodatku askorbinske kiseline $u$ vrednosti od $0,5 \%$.

Kontrolni uzorak konvektivno je osušen bez dodatka askorbinske kiseline. Ukupna promena boje kontrolnog uzorka osušenog vazduhom temperature $45^{\circ} \mathrm{C}$ je $\Delta E=22,95$, odnosno $\triangle E=25,71$ pri temperaturi vazduha od $65^{\circ} \mathrm{C}$.

Za aproksimaciju eksperimentalnih rezultata kinetkie konvektivnog susenja korišćeni su pet matematickih modela koji se mogu naci u referentnoj literaturi iz ove oblasti (Newton, Page, Modified Page, Henderson and Pabis and Logarithmic), proširenih bezdimenzionalnim koeficijentom koji predstavlja temperaturu vazduha za sušenje. Na osnovu vrednosti statističkih pokazatelja $R, X^{2}$ i RMSE može se zaključiti da Prošireni Modifikovani Page model najbolje aproksimuje kinetiku konvektivnog sušenja kaše od kruške.

Ključne reči: jagoda, kinetika konvektivnog sušenja, matematičko modelovanje, promena boje, voćne rolnice.

\section{INTRODUCTION}

In the production of dried fruit, certain fruits do not respond to the technological processes of drying and are, therefore, used for other types of processing. Fruit leather rolls (rolls of dried fruit pulp) are one of the processed fruit products found in the market. The production of fruit leather rolls encompasses the following procedures: fruits are blended into a pulp, set on drying trays in fixed thin layers (4-5 mm thick), dried, and ultimately cut in ribbons which are used to form rolls. During the preparation of the fruit pulp and its convective drying, the oxidation process occurs causing it to darken. In order to reduce the effect of oxidation, antioxidants such as L-ascorbic acid are added to the prepared pulp (Vakula et al., 2015; Radojčin, et al., 2010; Ratti 2011). As convective drying exerts a degrading effect on the content of L-ascorbic acid, the addition of Lascorbic acid increases the content of L-ascorbic acid in finished products, thus preserving their color (Stamenković, 2018).

The mathematical models of convective drying most often found in the literature were examined in the present study to find a model that is highly responsive to the convective drying of strawberry pulp (Serdar et al., 2016 ; Vega-Gálvez et al., 2009; 
Pavkov, 2012; Tepić, 2012; Menges and Ertekin 2006; Doymaz, 2005; Mierzwa et al., 2019). Furthermore, the mathematical models were extended with a dimensionless coefficient, i.e. the temperature of drying air (Pavkov et al., 2013; Pavkov et al., 2012; Babić et al., 2004). The mathematical modeling of the kinetics of drying biomaterials is the basis of the development of the drying system, the selection of optimal drying conditions and the prediction of the mass and heat transfer in biomaterials.

The purpose of the paper is to define the extended mathematical model of the kinetics of strawberry pulp convective drying and to examine the effect of air temperature and the addition of L-ascorbic acid to strawberry pulp on changes in the color of final products.

Furthermore, the effective moisture diffusivity and the activation energy were estimated for the additional description of strawberry pulp drying mechanisms.

\section{MATERIAL AND METHOD}

\section{Materials}

Fresh strawberries were obtained from local producers in the area of Novi Sad. The fully ripe and mature strawberry fruits were stored in a cooling chamber at a temperature of $3-4{ }^{\circ} \mathrm{C}$. Shortly before the experiment was carried out, the strawberries were kept for a certain time at room temperature in order to equalize the temperatures of the fruit and the environment. The preparation of strawberries involved stem removal and subsequent blending to the pulpous structure using a laboratory blender. The fresh strawberry pulp moisture was about $86 \%$.

\section{Methods}

It was a two-factor experiment. The first factor was the air temperature needed for drying, namely $45^{\circ} \mathrm{C}$ and $65^{\circ} \mathrm{C}$. The second factor of the experiment was the adding of ascorbic acid to the strawberry pulp, prior to the drying process, in the amounts of $0.5 \%$ and $1 \%$ of the full mass of the prepared fruit pulp. The fruit pulp was dried at a constant air speed of $1.5 \mathrm{~m} \cdot \mathrm{s}^{-1}$ and with an average absolute air humidity of $0.0102 \mathrm{~g}_{\mathrm{w}} / \mathrm{g}_{\text {dair }}$. In each experiment, a total of $1500 \mathrm{~g}$ of the prepared pulp was set on a tray, in a 5 mm-thick layer, in a laboratory convective dryer (Pavkov, 2012).

The experiment was conducted in triplicate as a full factorial experiment. Moreover, a control experiment was also carried out, without the addition of ascorbic acid.

The color of the strawberry pulp was measured immediately after blending and after the drying process using the Konika Minolta CR-400 colorimeter. The color of all the samples was measured at 10 different measurable surfaces.

The color was represented in the CIE $\mathrm{L}^{*}$ (whiteness/brightness), $\mathrm{a}^{*}$ (redness/greenness) and $\mathrm{b}^{*}$ (yellowness/blueness) color scheme. The total color difference $(\Delta \mathrm{E})$, hue angle for dried material, $\left(\mathrm{h}^{\mathrm{o}}\right)$, hue angle for fresh material $\left(\mathrm{h}_{\text {fresh }}\right)$, and chromaticity $\left(\mathrm{C}^{*}\right)$ were expressed in Eqs. 1, 2, 3 and 4. (Radojčin et al., 2010; Maskan, 2001):

$$
\begin{aligned}
& \Delta \mathrm{E}=\sqrt{\left(\mathrm{L}^{*}-\mathrm{L}_{0}\right)^{2}+\left(\mathrm{a}^{*}-\mathrm{a}_{0}\right)^{2}+\left(\mathrm{b}^{*}-\mathrm{b}_{0}\right)^{2}} \\
& \mathrm{~h}^{\mathrm{o}}=\arctan \left(\frac{\mathrm{b}^{*}}{\mathrm{a}^{*}}\right) \\
& \mathrm{h}_{\text {fresh }}=180+\arctan \left(\frac{\mathrm{b}_{0}}{\mathrm{a}_{0}}\right) \\
& \mathrm{C}^{*}=\left(\sqrt{\left(a^{* 2}+b^{* 2}\right)}\right),
\end{aligned}
$$

where, $\mathrm{L}_{0}, \mathrm{a}_{0}, \mathrm{~b}_{0}$ are the color values before drying, while $\mathrm{L}^{*}, \mathrm{a}^{*}, \mathrm{~b}^{*}$ are the color values after drying.

The kinetics of convective drying was measured using a laboratory convective dryer, featuring the ability to continuously measure the sample mass during the drying process (Pavkov, 2012). Changes in the mass of the fruit pulp during the drying process and changes in the drying air temperatures were recorded at 5-min intervals using the laboratory acquisition National Instrument.

The data obtained from the air drying test were then expressed as the moisture radio (MR), calculated according to the following equation:

$$
\mathrm{MR}=\frac{\mathrm{X}_{\mathrm{t}}-\mathrm{X}_{\mathrm{eq}}}{\mathrm{X}_{0}-\mathrm{X}_{\mathrm{eq}}}
$$

where $X_{t}, X_{0}, X_{e q}$, are the moisture content at the time $t\left(g / g_{d . b}\right.$.), the initial moisture content $\left(\mathrm{g} / \mathrm{g}_{\text {d.b. }}\right)$ and the equilibrium moisture content (g/g d.b.), respectively.

The drying curves (MR) were fitted by means of five extended mathematical models of moisture ratio that are widely used in food and biological material studies (Table 1.). Consequently, the model that fits best to the experimental results of drying kinetics can be used for the approximation of strawberry pulp convective drying at air temperatures $45-65{ }^{\circ} \mathrm{C}$ an an air velocity of $1.5 \mathrm{~m} \cdot \mathrm{s}^{-1}$.

The correlation coefficient $(\mathrm{R})$, the reduced chi - square $\left(\mathrm{X}^{2}\right)$ and the root mean square error (RMSE) were used as the primary criteria for selecting the best equation for the variation in the drying curves of the dried samples. The reduced $\mathrm{X}^{2}$ is used to determine the accuracy of the fit. The lower the values of the reduced $\mathrm{X}^{2}$, the better the accuracy of the fit. The RMSE accounts for the deviation between the predicted and experimental values and it is required to reach zero (Megnes and Ertekin, 2006 Pavkov et al., 2012; Doymaz, 2008; Menges et al., 2006, Naderinezhad et al., 2016; Lee and Hsieh, 2008).

As an indicator of change in the drying rate over time, the mean rate of moisture content change is calculated using the following equation (Pavkov et al., 2010; Pavkov et al., 2012):

$$
\frac{\Delta \omega_{i}^{\mathrm{s}}}{\Delta \tau}=\frac{X_{i+1}^{\mathrm{s}}-X_{i}^{\mathrm{s}}}{\Delta \tau},
$$

where $X_{i+1}^{s}$ - the moisture content of the dry basis measured after $X_{i}^{s}$ at time interval $\tau_{\text {int }}\left(\mathrm{g} / \mathrm{g}_{\mathrm{d} . \mathrm{b}}\right)$; $\omega_{\mathrm{i}}^{\mathrm{s}}$ - the moisture content at the moment ( $\mathrm{g} / \mathrm{g}_{\mathrm{d} . \mathrm{b}}$ ), and $\Delta \tau$ - the time of periodic data collection (min).

Table 1. Mathematical models applied to the drying curves

\begin{tabular}{|c|c|c|c|c||}
\hline No. & Name of model & Model & References & Extended form of model \\
\hline 1. & Newton & $\mathrm{MR}=\exp (-\mathrm{kt})$ & Bon et al., 2007 & $\mathrm{MR}=\exp \left(-\mathrm{kt} \cdot\left(\tau_{\mathrm{e}} / \tau_{\mathrm{ref}}\right)^{\mathrm{n} 2}\right)$ \\
\hline 2. & Page & $\mathrm{MR}=\exp \left(-\mathrm{kt}{ }^{\mathrm{n}}\right)$ & Hassan-Beygi et al 2009 & $\mathrm{MR}=\exp \left(-\mathrm{kt} t^{\mathrm{n} 1} \cdot\left(\tau_{\mathrm{e}} / \tau_{\mathrm{ref}}\right)^{\mathrm{n} 2}\right)$ \\
\hline 3. & Modified Page & $\mathrm{MR}=\exp \left[-(\mathrm{kt})^{\mathrm{n}}\right]$ & Overhults et al. 1973 & $\mathrm{MR}=\exp \left[-(\mathrm{kt})^{\mathrm{n} 1} \cdot\left(\tau_{\mathrm{e}} / \tau_{\mathrm{ref}}\right)^{\mathrm{n} 2}\right]$ \\
\hline 4. & Hend. and Pabis & $\mathrm{MR}=\operatorname{aexp}\left(-\mathrm{k}_{0} \mathrm{t}\right)$ & Hend. and Pabis, 1961 & $\mathrm{MR}=\operatorname{aexp}\left(-\mathrm{k}_{0} \mathrm{t} \cdot\left(\tau_{\mathrm{e}} / \tau_{\mathrm{ref}}\right)^{\mathrm{n} 2}\right)$ \\
\hline 5. & Logarithmic & $\mathrm{MR}=\operatorname{aexp}(-\mathrm{kt})+\mathrm{c}$ & Bon et al., 2007 & $\mathrm{MR}=\operatorname{aexp}\left(-\mathrm{kt} \cdot\left(\tau_{\mathrm{e}} / \tau_{\mathrm{ref}}\right)^{\mathrm{n} 2}\right)+\mathrm{c}$ \\
\hline
\end{tabular}

* $k$ - drying constant; $n 1, n 2$ - model exponent; $a$, c - model coefficients; $t$ - drying time;

$\tau_{e}$-drying air temperature; $\tau_{\text {ref }}$ - referent drying air temperature $\left(\tau_{\text {ref }}=45^{\circ} \mathrm{C}\right)$ 
The calculated values are presented in Figure 2 as the kinetic curves of the mean drying rate $\left(\Delta \omega_{\mathrm{i}}^{\mathrm{s}} / \tau\right)$.

As the mechanism of drying depends on the moisture diffusion from a place of lower to a place of higher concentration, the Fick's second law of diffusion has been frequently used to describe the moisture transfer (Lee and Hsieh 2008; Doymaz, 2005; Doymaz, 2008). Crank (1975) developed the solution Fick's diffusion equations for different shapes of drying materials. For drying materials such as fruit pulps dried in a thin stagnant layer, the Crank's equation for a semi-infinite plane sheet fits the best (Crank, 1975; Lee and Hsieh 2008; Doymaz, 2011).

$$
\mathrm{MR}=\frac{8}{\pi^{2}} \sum_{\mathrm{n}=0}^{\infty} \frac{1}{(2 \mathrm{n}+1)^{2}} \exp \left(-\frac{(2 \mathrm{n}+1)^{2} \pi^{2} \mathrm{D}_{\mathrm{eff}} \mathrm{t}}{4 \mathrm{~L}^{2}}\right)
$$

where $D_{\text {eff }}$ is the effective moisture diffusivity $\left(\mathrm{m}^{2} \cdot \mathrm{s}^{-1}\right)$; $t$ is the drying time (s); $\mathrm{L}$ is the half-thickness of samples (m) and $\mathrm{n}$ is a positive integer. For longer drying times ( $>60 \mathrm{~min}$ ), a limitation of Eq. 7 is obtained and expressed in the following logarithmic form (Lee and Hsieh 2008; Doymaz, 2011):

$$
\ln M R=\ln \left(\frac{\mathrm{X}_{\mathrm{t}}-\mathrm{X}_{\mathrm{eq}}}{\mathrm{X}_{0}-\mathrm{X}_{\mathrm{eq}}}\right)=\ln \left(\frac{8}{\pi^{2}}\right)-\left(\frac{\pi^{2} \mathrm{D}_{\mathrm{eff}} \mathrm{t}}{4 \mathrm{~L}^{2}}\right)
$$

From Eq. 8, a plot of $\ln (\mathrm{MR})$ versus the drying time gave a straight line with a slope $(\mathrm{K})$ which is related to the effective moisture diffusivity (Wang, 2007; Aregbesola, 2015; Doymaz, 2007):

$$
\mathrm{K}=\frac{\pi^{2} \mathrm{D}_{\text {efft }}}{4 \mathrm{~L}^{2}}
$$

Effective moisture diffusivity depends on the temperature of drying materials, which is correlated with the energy needed to move one mole of steam over a distance of one angstrom (1 A = $10^{-10} \mathrm{~m}$ ) (Židtko, 1982; Pavkov, 2012; Valent, 2001; Babić, 2012). That energy is called the activation energy $E_{a}\left(k J \cdot \mathrm{mol}^{-1}\right)$ and it is described by the Arrhenius equation (Aral, 2016; Wang, 2007; Aregbesola, 2015; Doymaz, 2011):

$$
\mathrm{D}_{\text {eff }}=\mathrm{D}_{0} \exp \left(-\frac{\mathrm{E}_{\mathrm{a}}}{\mathrm{R}(\mathrm{T}+273.15)}\right)
$$

where $\mathrm{D}_{0}$ is the pre-exponential factor of the Arrhenius equation $\left(\mathrm{m}^{2} \cdot \mathrm{s}^{-1}\right) ; \mathrm{E}_{\mathrm{a}}$ is the activation energy $\left(\mathrm{kJ} \cdot \mathrm{mol}^{-1}\right) ; \mathrm{R}$ is the universal gas constant (for air $\left.0,00831 \mathrm{~kJ} \cdot(\mathrm{mol} \mathrm{K}){ }^{-1}\right)$ and $\mathrm{T}$ is the air temperature $\left({ }^{\circ} \mathrm{C}\right)$.

\section{RESULTS AND DISCUSSION}

\section{Color change}

The measured values in the CIE color system $\mathrm{L}^{*}, \mathrm{a}^{*}$ and $\mathrm{b}^{*}$, after the drying process, with a total color difference $(\Delta \mathrm{E})$, hue angle $\left(\mathrm{h}^{\circ}\right)$ and chromaticity $\left(\mathrm{C}^{*}\right)$ are shown in Table 2 . The analysis of the measured values indicates that the smallest change in the sample color was accomplished by adding ascorbic acid in the amount of $1 \%$ of the pulp mass at a drying air temperature of $65^{\circ} \mathrm{C}$ (the total change of color $\Delta \mathrm{E}=12.57$ )

The greatest change in the sample color was accomplished at a drying air temperature of $45^{\circ} \mathrm{C}$ by adding ascorbic acid in the amount of $0.5 \%(\Delta E=14.66)$. The change in the control sample color, with no ascorbic acid added, amounted to $\Delta \mathrm{E}=22.95$, at an air temperature of $45^{\circ} \mathrm{C}$, whereas the total change in the control sample color was $\Delta \mathrm{E}=18.99$ at a drying air temperature of $65^{\circ} \mathrm{C}$. Such results were expected since higher amounts of additional ascorbic acid lead to enhanced color preservation, and higher drying air temperatures lead to a decrease in the material drying time, which is conducive to preserving the material color. The statistical importance of the effects of the experimental factors, as well as their interaction, is shown in Table 3. Based on the analysis of variance, the content of ascorbic acid and the drying air temperature, as well as their interaction, were found to exhibit a statistically significant effect on the preservation of the sample color during convective drying.

Table3. Effects of the experimental factors on strawberry pulp color change

\begin{tabular}{||c|c|c|c||}
\hline \hline Effect & F value & F distribution & $\mathrm{p}$ \\
\hline Intercept & 7945.97 & 3,94 & 0.000000 \\
\hline Air temp. & 364.41 & 3,94 & 0.000000 \\
\hline $\begin{array}{c}\text { Ascorbic } \\
\text { acid cont. }\end{array}$ & 63.34 & 3,94 & 0.000000 \\
\hline $\begin{array}{c}\text { Air temp. } \\
\text { Asc. acid cont. }\end{array}$ & 22.93 & 3,94 & 0.000006 \\
\hline
\end{tabular}

\section{Drying kinetics}

The statistical parameters of five extended mathematical models of strawberry pulp convective drying (namely $\mathrm{R}, \mathrm{X}^{2}$, RMSE) are shown in Table 4 . Table 5 shows the constants and the coefficients of the extended mathematical models for the kinetics of strawberry pulp convective drying at temperatures of $65^{\circ} \mathrm{C}$ and $45^{\circ} \mathrm{C}$. The Extended Modified Page model showed the best fit for the convective drying of strawberry pulp in a thin layer. The correlation coefficient for the Extended Modified Page model is $\mathrm{R}=0.9865$. Furthermore, this model had the lowest value of the reduced $\mathrm{X}^{2}=0.0026$ and the lowest value of RMSE $=0.05115$. The entire process of strawberry pulp convective drying at a temperature of $65{ }^{\circ} \mathrm{C}$ required around 540 min. Within that period, the moisture of the pulp was reduced from the initial moisture $\omega_{\mathrm{db}}=6.14 \mathrm{~g} / \mathrm{g}_{\mathrm{d} . \mathrm{b}}$ ( $86 \%$ moisture relative to the moisture base) to $\omega_{\mathrm{tdb}}=0.11 \mathrm{~g} / \mathrm{g}_{\mathrm{d} . \mathrm{b}}(10 \%$ moisture relative to the moisture base). The strawberry pulp convective drying at a temperature of $45^{\circ} \mathrm{C}$ lasted longer than in the previous case and required $600 \mathrm{~min}$.

The experimental results of the kinetics of strawberry pulp convective drying and the results of the predicted kinetics using the Extended Modified Page are shown in Table 4 and Figure 1. 
Table4. Statistical results of four extended mathematical models for strawberry pulp convective drying

\begin{tabular}{||c|c|c|c||}
\hline \hline \multirow{2}{*}{$\begin{array}{c}\text { Name of the } \\
\text { extended } \\
\text { model }\end{array}$} & \multicolumn{3}{|c|}{ Statistical coefficients } \\
\cline { 2 - 4 } & $R$ & $X^{2}$ & $R M S E$ \\
\hline Newton & 0.97096934 & 0.005605 & 0.07479 \\
\hline Page & 0.986517 & 0.002624 & 0.05117 \\
\hline Modified Page & 0.986527 & 0.002622 & 0.05115 \\
\hline Henderson and Pabis & 0.977331332 & 0.004391 & 0.06619 \\
\hline Logarithmic & 0.984409 & 0.003031 & 0.05499 \\
\hline
\end{tabular}

Table 5. Constants and coefficient of the extended mathematical model for strawberry pulp convective drying at an air temperature of $45^{\circ} \mathrm{C}$

\begin{tabular}{|c|c|c|c|c|c|}
\hline \multirow{2}{*}{$\begin{array}{c}\text { Name of } \\
\text { extended } \\
\text { model }\end{array}$} & & \multicolumn{4}{|c|}{ 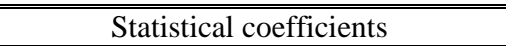 } \\
\hline & $a$ & $k$ & $n_{1}$ & $n_{2}$ & $C$ \\
\hline Newton & & 0.00406 & & 1.18030 & \\
\hline Page & & 0.00044 & 1.39232 & 1.61075 & \\
\hline $\begin{array}{l}\text { Modified } \\
\text { Page }\end{array}$ & & 0.00388 & 1.40456 & 1.62799 & \\
\hline $\begin{array}{l}\text { Henderson } \\
\text { and Pabis }\end{array}$ & 1.11988 & 0.00452 & & 1.17343 & \\
\hline Logarithmic & 1.19997 & 0.00338 & & 1.08944 & -0.13245 \\
\hline
\end{tabular}

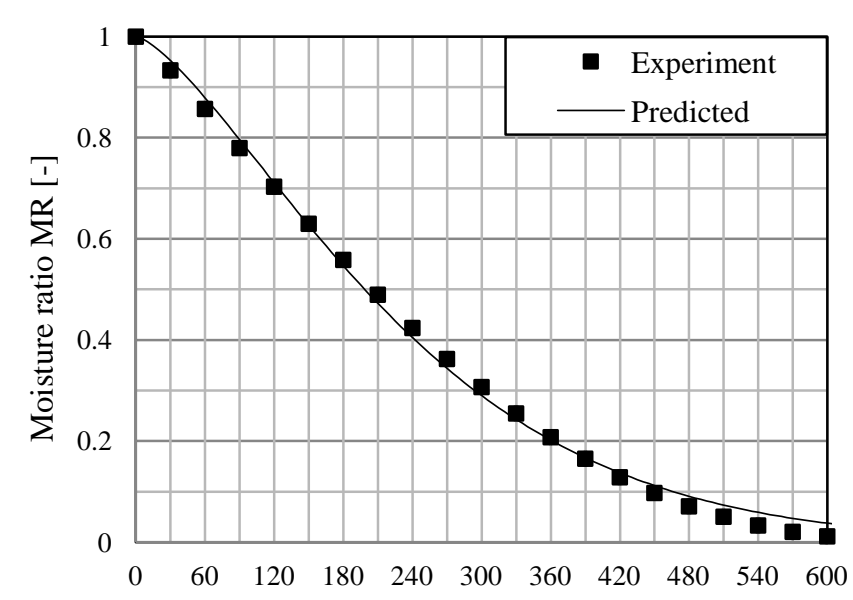

Time $\Delta \tau[\mathrm{min}]$

a)

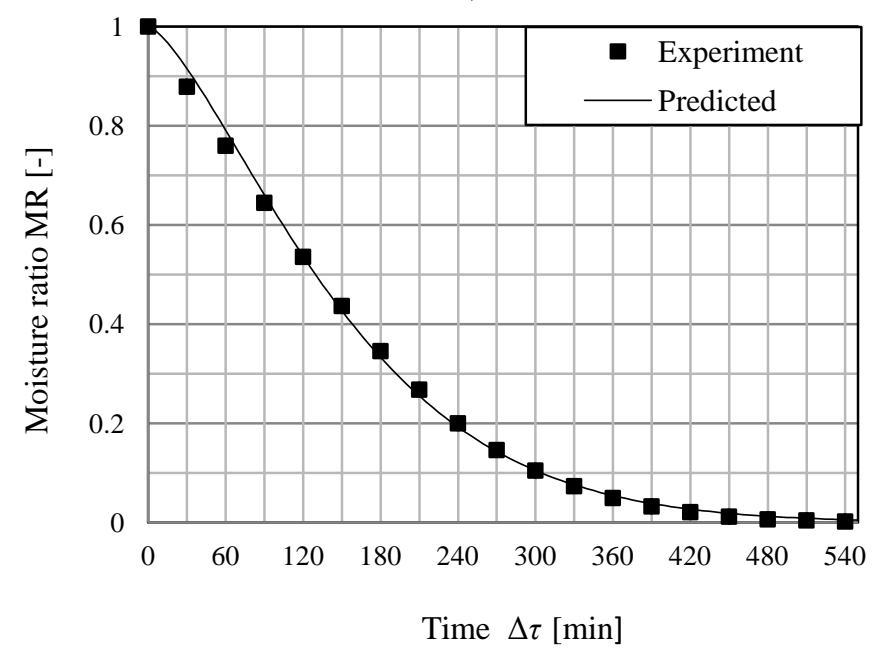

b)

Fig. 1. Experimental and predicted curves of the Extended Modified Page model moisture ratio for strawberry pulp convective drying at air temperatures of $45^{\circ} \mathrm{C}$ (a) and $65^{\circ} \mathrm{C}(\mathrm{b})$

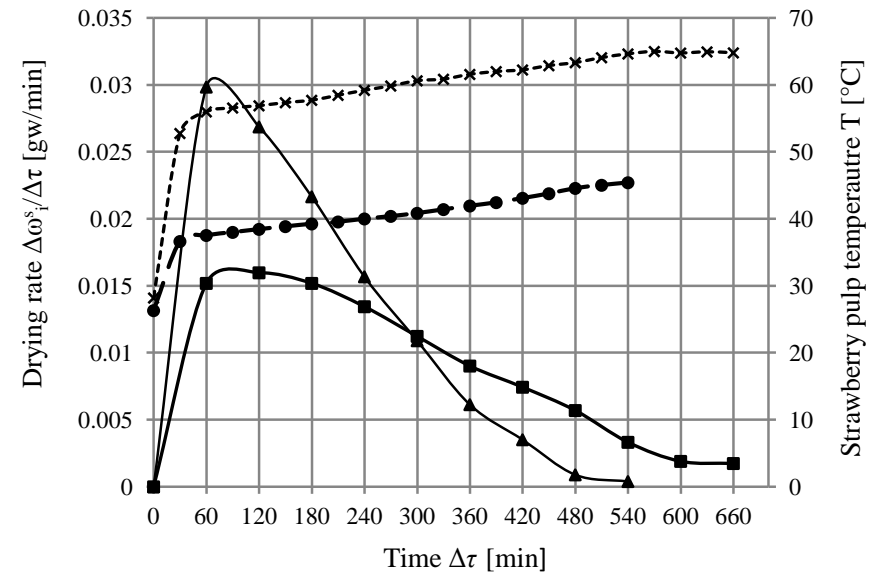

Drying rate at air temperature $65^{\circ} \mathrm{C}$
Drying rate at air temperature $45^{\circ} \mathrm{C}$
Pulp temperature at air temperature of $45^{\circ} \mathrm{C}$

Fig. 2. Drying rates of moisture content change calculated relative to the dry basis of strawberry pulp during convective drying at air temperatures of $45^{\circ} \mathrm{C}$ and $65^{\circ} \mathrm{C}$

The kinetic curves of strawberry pulp drying rates at drying air temperatures of 45 and $65{ }^{\circ} \mathrm{C}$ indicate similar trends, reaching their maximum within the first hour of drying. This period of drying is characterized by a considerable increase in the drying rate due to the evaporation of surface moisture. Furthermore, in the first hour of drying, the strawberry pulp temperature has a period of increasing heating rates, while the diffusion coefficient reaches its maximum value. Thereafter, the drying rate gradually and linearly decreases. This is considered a consequence of the formation of dry surface layers, which hinder the moisture diffusion to the surface of the material. In this drying period, the moisture content also exhibits a linearly decreasing trend, until the equilibrium moisture content is reached. Moreover, the diffusion coefficient also gradually decreases, whereas the strawberry pulp temperature gradually increases until the temperature of drying air is reached.

\section{Effective moisture diffusivity and activation energy}

The linear estimates of $\ln (\mathrm{MR})$, versus the drying time without intercept, were satisfactory fitted to the experimental data, with the correlation coefficient $\mathrm{R}^{2}>0.95$ for both drying air temperatures under consideration (Fig. 3). The obtained slope values (K) were 0.0044 and 0.0067 for $45{ }^{\circ} \mathrm{C}$ and $65{ }^{\circ} \mathrm{C}$, respectively. The moisture diffusivity $\mathrm{D}_{\text {eff }}$ is further estimated by Eq. 9, and it was $1.115 \times 10^{-8} \mathrm{~m}^{2} \cdot \mathrm{s}^{-1}$ and $1,698 \mathrm{~m}^{2} \cdot \mathrm{s}^{-1}$, for $45^{\circ} \mathrm{C}$ and $65^{\circ} \mathrm{C}$, respectively.

The activation energy for diffusion was calculated from the slope of a straight line by plotting $\ln \left(\mathrm{D}_{\text {eff }}\right)$ versus the reciprocal of the air temperature, 1/T (Fig. 4) (Doymaz, 2007). The slope of the line is -2261.9 and it is equal to $-\mathrm{E}_{\mathrm{a}} \cdot \mathrm{R}^{-1}$ and the intercept equals $\ln \left(D_{0}\right)$. The activation energy calculated from the slope of the straight line in Fig. 4 was found to be $18.806 \mathrm{~kJ} \cdot \mathrm{mol}^{-1}$.

Comparable results were presented by Lee and Hsieh, 2008. In their paper, strawberry pulp was convectively dried at air temperatures of $50,60,70$ and $80^{\circ} \mathrm{C}$ and the thickness values of the dried layer were 1.8, 2.7 and $3.6 \mathrm{~mm}$. The results obtained at an air temperature of $60{ }^{\circ} \mathrm{C}$ and a thickness of $3.6 \mathrm{~mm}$ were $D_{\text {eff }}$ $=6.24 \times 10^{-9} \mathrm{~m}^{2} \cdot \mathrm{s}^{-1}$ and $\mathrm{E}_{\mathrm{a}}=30.46 \mathrm{~kJ} \cdot \mathrm{mol}^{-1}$ (Lee and Hsieh, 2008). 


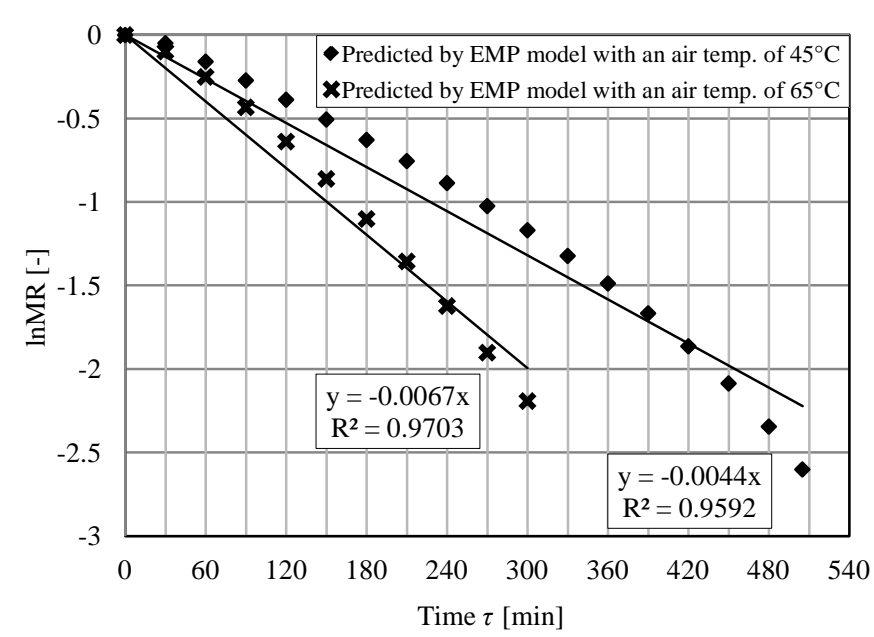

Fig. 3. Linear regression of $\ln (M R)$ versus the drying time $\tau$ without intercept for strawberry pulp of $5 \mathrm{~mm}$ thickness dried at air temperatures of $45^{\circ} \mathrm{C}$ and $65^{\circ} \mathrm{C}$

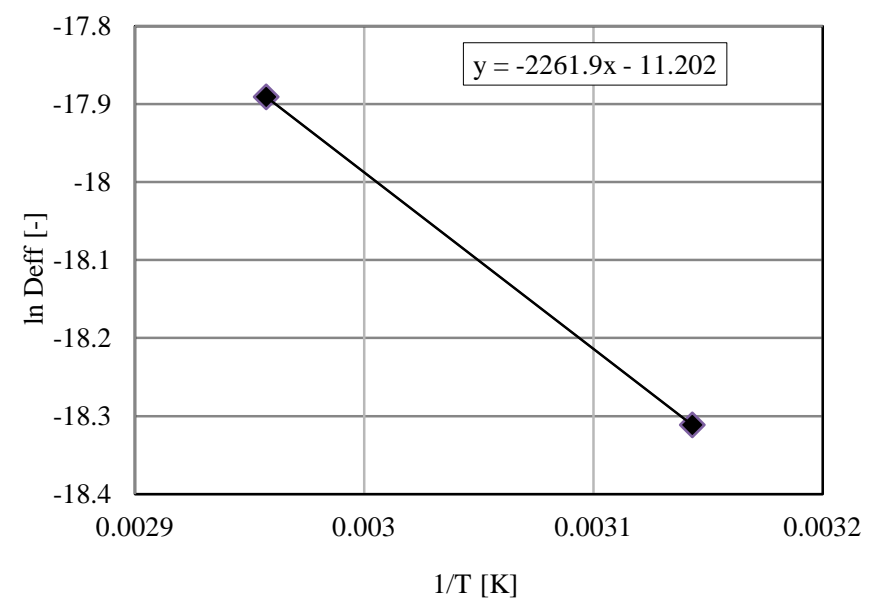

Fig. 4. Arrhenius relationship between the diffusivity and temperature

\section{CONCLUSION}

As expected, the greatest color change was recorded in the control sample, where no ascorbic acid was added $(\Delta \mathrm{E}=22.95$ and $\Delta \mathrm{E}=18.99$ at air temperatures of $45{ }^{\circ} \mathrm{C}$ and $65{ }^{\circ} \mathrm{C}$, respectively).

The smallest change in the strawberry pulp sample color $(\Delta \mathrm{E}=12.57)$ was found during convective drying with the addition of ascorbic acid (in the amount of $1 \%$ ) at a drying air temperature of $65{ }^{\circ} \mathrm{C}$. This can be accounted for by the shortest drying time and exposure to the oxidizing effect of air.

In the samples with added ascorbic acid, the greatest color change was achieved at a drying air temperature of $45^{\circ} \mathrm{C}$ and $0.5 \%$ of added ascorbic acid $(\Delta \mathrm{E}=14.66)$.

Upon dispersive analysis, it has been established that the amount of ascorbic acid within the sample and the drying air temperature significantly affect changes in the sample color.

The statistical parameters the Extended Modified Page model (namely $\mathrm{R}, \mathrm{X}^{2}$ and RMSE) indicate the best fit of the model for the convective drying of strawberry pulp in a thin layer.

The correlation coefficient for the Extended Modified Page model is $\mathrm{R}=0.9865$. The model also has the lowest value of the reduced $\chi^{2}=0.0026$ and the lowest value of RMSE $=0.05115$.

The drying process of the strawberry pulp required around 540 and $600 \mathrm{~min}$ at drying air temperatures of $65^{\circ} \mathrm{C}$ and $45^{\circ} \mathrm{C}$, respectively. In that period, the moisture of the pulp was reduced from the initial $\omega_{\mathrm{db}}=6.14 \mathrm{~g} / \mathrm{g}_{\mathrm{d} . \mathrm{b}}$ ( $86 \%$ moisture relative to the moisture base) to $\omega_{\mathrm{tdb}}=0.11 \mathrm{~g} / \mathrm{g}_{\mathrm{d} . \mathrm{b}}(10 \%$ moisture relative to the moisture base).

The moisture diffusivity $D_{\text {eff }}$ is $1.115 \times 10^{-8} \mathrm{~m}^{2} \cdot \mathrm{s}^{-1}$ and 1.698 $\mathrm{m}^{2} \cdot \mathrm{s}^{-1}$, for $45^{\circ} \mathrm{C}$ and $65^{\circ} \mathrm{C}$ respectively, whereas the activation energy was found to be $18.806 \mathrm{~kJ} \cdot \mathrm{mol}^{-1}$.

ACKNOWLEDGEMENTS: This paper is a result of the research within the project TR31058, 2011-2020, supported by the Ministry of Education, Science and Technology, Republic of Serbia.

\section{REFERENCES}

Aral, S., Vildan Bese, A. (2016). Convective drying of hawthorn fruit (Crataegus spp.): Effect of experimental parameters on drying kinetics, color, shrinkage, and rehydration capacity. Food Chemistry. 210, 577-584.

Aregbesola, O. A; Ogunsina, B.S; Sofolahan, A.E; Chime, N.N. (2015).

Mathematical

modelingofthinlayerdryingcharacteristicsof dika (Irvingiagabonensis) nutsandkernels. Nigerian Food Journal, 33, 83-89.

Babić, Lj., Babić. M. (2012). Sušenje i skladištenje. Udžbenik, Poljoprivredni fakultet. Novi Sad, Srbija

Babić, Ljiljana, Babić, M., Pavkov, I. (2004). Uticajni faktori na promenu vlažnosti polutki kajsije pri osmotskom sušenju. Savremena poljoprivredna tehnika, Novi Sad, 30 (3-4), 117126.

Bon, J., Rossello, C., Femenia, A., Eim, V., Simal, S. (2007). Mathematical modeling of drying kinetics for apricots. Influence of the external resistance to mass transfer. Drying Technology, 25, 1829-1835.

Crank, J. (1975). The mathematics of diffusion. Oxford, England: Clarendon Press.

Doymaz, I. (2005). Drying characteristics and kinetics of okra. Journal of Food Engineering, 69, 275-279.

Doymaz, I. (2007). Air-drying characteristics of tomatoes. Journal of Food Engineering, 78, 1291-1297.

Doymaz, I. (2008). Convective drying kinetics of strawberry. Chemical Engineering and Processing, 47, 914-919.

Doymaz, I. (2011). Thin-layer drying characteristics of sweet potato slices and mathematical modelling. Heat Mass Transfer, 47, 277-285.

Hassan-Beygi, S.R., Aghbashlo, M., Kianmehr, M.H., Massah, J. (2009). Drying characteristics of walnut (Juglans regiaL.) during convection drying. International Agrophysics, 23, 29135.

Henderson, S.M., Pabis, S. (1961). Grain drying theory. I.Temperature effect on drying coefficient. Journal of Agricultural Engineering Research, 6 (3), 169-174.

Lee, G., Hsieh, F. (2008). Thin-layer drying kinetics of strawberry fruit leather. American Society of Agricultural and Biological Engineers, 51 (5), 1699-1705.

Maskan, M. (2001). Kinetics of colour change of kiwifruits during hot air and microwave drying. Journal of Food Engineering, 48, 169-175.

Menges, O.H., Ertekin, C. (2006). Mathematical modeling od thin layer drying od Golden apples. Journal of Food Science, 77, 119-125.

Mierzwa, D., Szadzińska, J., Pawłowski, A., Pashminehazar, R., Kharaghani, A. (2019). Nonstationary convective drying of raspberries, assisted by microwaves and ultrasound. Drying Technology, 37 (8), 988-1001. 
Naderinezhad, S., Etesami,, N., Najafabady, P., A., Falavarjani, G., M. (2016). Mathematical modeling of drying of potato slices in aforced convective dryer based on important parameters. Food Science \& Nutrition, 4 (1), 110-118.

Overhults, D. G., H. E. White, H. E. Hamilton, I. J. Ross, (1973). Drying soybeans with heated air. Transactions of American Society of Agricultural Engineers, 16, 112-113.

Pavkov, I. (2012). Kombinovana tehnologija sušenja voćnog tkiva. Doktorska disertacija. Poljoprivredni fakultet, Novi Sad, Srbija.

Pavkov, I., Babić, Ljiljana., Babić, M., Radojčin, M., Stamenković, Z. (2013). Mathematical modelling of convective drying nectarinehalves (Pyrus Persica L.). Savremena poljoprivredna tehnika, 39 (2), 103-112.

Pavkov, I., Babić, LJiljana., Babić, M., Radojčin, M., Stojanović, Č. (2010). Effects of osmotic dehydration factors on convective drying kinetics of pears slices (Pyrus Communis L.). Journal on Processing and Energy in Agriculture, 14 (3), 125-130.

Radojčin, M., Babić, M., Pavkov, I., Stamenković, Z. (2010). Color parameters change of quince during combined drying. Journal on Processing and Energy in Agriculture, 14 (2), 8184.

Ratti, C., (2001). Hot air and freeze-drying of high-value foods: a review. Journal of Food Engineering, 49, 311-319.
Stamenković, Z., Dolovac, A., Pavkov, I., Bursić, V., Radojčin, M., Babić, M., Kešelj, K. (2018). Convective drying of organic pear pulp in a thin stagnant layer. Journal on Processing and Energy in Agriculture, 21 (4), 153-156.

Tepić, Aleksandra (2012). Bojene materije voća i povrća. Tehnološki fakultet, Novi Sad, Srbija

Vakula, Anita, Radojčin, M., Pavkov, I., Stamenković, Z., Tepić Horecki, Aleksandra, Šumić, Z., Pavlić, B. (2015). The impact of different drying methods on quality indicators of red currants (ribesrubrum 1.). Journal on Processing and Energy in Agriculture, 19 (5), 249-254.

Valent, V. (2001). Sušenje u procesnoj indrustriji. Monografija, Tehnološko - metalurški fakultet, Beograd, Srbija.

Vega-Galvez, A., Lopez, Jessica, Miranda, Margarita, Di Scala, Karina, Yagnam, F., Uribe, Elsa, (2009). Mathematical modelling of moisture sorption isotherms and determination of isosteric heat of blueberry variety O’Neil. Food Science \& Technology, (44), 2033-2041.

Wang, Z; Junhong, S; Liao, X; Chen, F; Zhao, G; Wu, J; Hu, X; (2007). Mathematical modeling on hot air drying of thin layer apple pomace. Food Research International, 40, 39-46.

Židtko, V.I., Rezičkov. V.A., Ukolov, B.S. (1982). Zernosušenie i zernosušilki. Kolos, Moskva, Rusija.

Received: 27. 11. 2019.

Accepted: 09. 12. 2019. 